\title{
Use of a GnRH synthetic analog (buserelin) for estrous induction in female dogs
}

\author{
[Utilização de análogo sintético de GnRH (buserelina) na indução do estro em cadelas] \\ R.S. Rezende ${ }^{1}$, D. Eurides ${ }^{2}$, C.P. Barbosa ${ }^{3}$, M.S. Lacerda $^{3}$, R.L. Sampaio ${ }^{3}$, A.L. Gomes ${ }^{3}$ \\ ${ }^{1}$ Aluno de pós-graduação - Universidade Federal de Uberlândia - Uberlândia, MG \\ ${ }^{2}$ Universidade Federal de Uberlândia - Uberlândia, MG \\ ${ }^{3}$ Universidade de Uberaba - Uberaba, MG
}

\begin{abstract}
The aim of this study was to evaluate the effectiveness of a GnRH synthetic analog, as an estrous inducer in female dogs when administered during the anestrous phase, and to evaluate the pregnancy rate achieved through natural copulation. For this purpose, ten female dogs of different breeds were used. The subjects received buserelin by intramuscular injections at a dose of $2,1 \mathrm{mcg}$ when female dogs weighed up to $10 \mathrm{~kg}$ (Group 1) and of 4,2mcg when the dogs weighed above 10kg (Group 2). Of the ten subjects, only three presented estrus after a single injection of buserelin: two dogs from Group 1 and one dog from Group 2 on average $7 \pm 1.29$ days. The remaining seven dogs were given a second dose of buserelin, equal to the first administration. Of these, three belonged to Group 1 and four to Group 2. Four of these dogs exhibited clinical signs of estrus within, on average $9 \pm 7.3$ days from the second injection. The seven female dogs that did enter estrus were fertilized successfully through natural copulation. The administration of buserelin was effective in inducing estrus in female dogs during the anestrous phase, with a maximum of two administrations.
\end{abstract}

Keywords: dogs, reproduction, hormone, cytology, cycle

\section{RESUMO}

Objetivou-se avaliar a eficácia de um análogo sintético ao GnRH como indutor de estro em cadelas em anestro e a taxa de prenhez por meio de cópula natural. Para isso, foram utilizadas 10 fêmeas caninas de diferentes raças. Cadelas de até $10 \mathrm{~kg}$ de peso (grupo 1) foram submetidas à administração de buserelina por via intramuscular, na dose de 2,1mcg, e cadelas acima de 10kg (grupo 2) foram submetidas à mesma medicação, porém na dose de 4,2mcg. Das fêmeas em anestro, apenas três apresentaram estro com

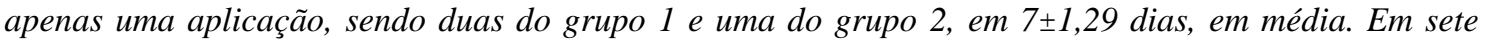
cadelas foi administrada mais uma dose de buserelina; destas, quatro eram pertencentes ao grupo 2 e três eram do grupo 1. Os sinais de estro ocorreram, em média, após 9+2,73 dias da segunda aplicação. As sete cadelas que manifestaram estro foram fertilizadas por meio de cópula natural. A administração de buserelina é eficiente para a indução de estro, em cadelas em anestro, em, no máximo, duas aplicações.

Palavras-chave: cães, reprodução, hormônio, citologia, ciclo

\section{INTRODUCTION}

The estrous cycle of female dogs has characteristics that differ from those of other species. Being monoestrous, they ovulate once or twice a year and present a similar luteal phase between pregnant and non-pregnant dogs. In addition, they undergo a period of several months of anestrus until the start of a new cycle (Concannon et al., 1989; Oliveira \& Marques Júnior, 2006).

The female dog's reproductive cycle has five different phases, established by hormonal

Recebido em 26 de novembro de 2016

Aceito em 25 de agosto de 2017

E-mail: rezendehvu@hotmail.com 
changes that induce morphological, clinical, and cytological transformations in the reproductive tract. These phases are proestrus, estrus, metestrus, diestrus, and anestrus. The period of sexual receptivity is called estrus (Ribeiro et al., 2007).

In vaginal smears, the relative ratio of different cell types can be used to identify the hormonal status and, therefore, the phase of the estrous cycle (Ribeiro et al., 2007).

Estrous induction in female dogs has been conducted to allow for mating purposes in a specific period, to terminate the prolonged anestrus due to undetermined causes, and to start the puberty period (Lanna et al., 2010; Ruiz et al., 2015).

There are many protocols to induce estrus in female dogs. However, according to Concannon and Verstegen (1997), these have not been sufficiently tested to become common practice. Furthermore, besides the difficulty in conducting the treatment, it is often expensive, further limiting its usage.

The main drugs that induce estrus in female dogs are prolactin inhibitors, both dopamine agonists and serotonin antagonists, prostaglandins and their analogs, GnRH, agonists and superagonists of GnRH, gonadotropins, and estrogens. Treatment efficacy in inducing fertile estrous varies according to the protocol used and the estrous cycle phase in which the treatment is conducted (Kutzler, 2005).

The synthetic analogs of GnRH have shown potential for induction of the estrous cycle. Buserelin is a synthetic GnRH agonist and often has a greater potential and stability when compared to the natural hormone. Its mechanism of action involves the direct stimulation of the pituitary gland. This stimulation causes the release of follicle-stimulating hormone (FSH) and luteinizing hormone (LH), thus resulting in a subsequent ovarian response (Lanna et al., 2010).

The development of an effective protocol for estrous induction in female dogs could be advantageous for dog breeding establishments, where the continuous birth of pups is required (England and Allen, 1991).
This study aimed to evaluate the efficacy of administering a synthetic analog of GnRH (buserelin) to induce estrus in female dogs during anestrus and to evaluate the pregnancy rate after natural mating.

\section{MATERIAL AND METHODS}

The study was approved by the Ethics Committee on Animal Experimentation of the University of Uberaba, opinion number 018/2016.

Ten female dogs of varying breeds were evaluated between February and August in 2016. The female dogs in anestrus were divided into two groups of equal number. Group 1 was comprised of female dogs weighing up to 10 kilograms, and Group 2 was comprised of female dogs weighing over 10 kilograms. The average age was $4.2 \pm 0.83$ years for Group 1 and $3.4 \pm 0.54$ years for Group 2. The dogs belonged to the Clinical Routine of the Animal Reproduction Sector of the Veterinary Hospital, where estrus needed to be anticipated for therapeutic or commercial reasons. All female dogs had a history of at least one previous pregnancy and an ideal body condition score (five).

The animals were evaluated using clinical, laboratory (hemogram), and imaging (reproductive system ultrasound) tests. The history of intervals between estrous cycles in female dogs in this study was on average $181 \pm 11.40$ days for Group 1 and 219 \pm 19.49 days for Group 2.

The female dogs from both groups were evaluated by vaginal cytology to determine anestrus. When vaginal cytology showed characteristics of low cellularity, with a predominance of parabasal cells, the female dogs were subjected to intramuscular administration of buserelin acetate (Sincroforte ${ }^{\circledR}$, Ouro Fino Saúde Animal, Brazil), a synthetic analog of GnRH. Dogs in Group 1 were administered a dose of $2,1 \mathrm{mcg}(0.5 \mathrm{~mL})$, and dogs in group 2 were administered a dose of $4,2 \mathrm{mcg}(1.0 \mathrm{~mL})$. Ten days after the administration, female dogs that did not start proestrus, characterized by vulvar edema and vaginal blood flow, received the same dosage again. After clinical manifestations of proestrus were noted, the 
animals were evaluated by cytological examination to confirm the induced estrus.

Each sample was collected for cytological evaluation by inserting a swab up to the cranial portion of the vagina, and moving the swab in rotary motions only in the dorsal part of the vagina for 20 seconds. After collection, the swab was immediately spread on microscope slides. Once dried, the slides were stained by the panoptic method. The slides were viewed using an optical microscope, with 400-x magnification, to assess the cell types of the vaginal epithelium. Cells involved include parabasal cells, small and large intermediate cells, superficial cells with pyknotic nuclei, and anucleate surface cells.

Estrus was confirmed when vaginal cytology revealed that over $80 \%$ of superficial cells were lacking their nuclei or displaying pyknotic nuclei, combined with the behavioral characteristic of this phase. The female dogs were then mated with males of their respective breeds, by natural mating, and without restriction on the number of copulations.
The results underwent descriptive statistical assessment of mean, standard deviation, and percentage. Fisher's exact test $(\mathrm{P}<0.05)$ was applied to evaluate the results of the induction between female dogs of the same group. The $G$ test $(\mathrm{P}<0.05)$ was then used to compare the results between the two groups.

\section{RESULTS AND DISCUSSION}

As shown in Table 1, only three of the ten females in anestrus showed clinical and cytological signs of estrus after receiving one administration of buserelin. Of these three, two were from Group 1 (receiving a dose of $2,1 \mathrm{mcg} /$ animal), and one was from Group 2 (receiving a dose of 4,2mcg/animal). All three female dogs that received only one dose of the drug showed signs of proestrus and later estrus, verified clinically and by vaginal cytology, on average of $7.0 \pm 1.29$ days after the administration.

Table 1. Number of administrations of buserelin and response to estrous induction in anestrous female dogs

\begin{tabular}{|c|c|c|c|c|c|c|}
\hline Group & $\begin{array}{l}\text { Weight } \\
\text { (kg) }\end{array}$ & $\begin{array}{c}\text { Age } \\
\text { (years) }\end{array}$ & $\begin{array}{c}\text { Interval } \\
\text { between } \\
\text { estruses } \\
\text { (days) }\end{array}$ & $\begin{array}{l}\text { Number of } \\
\text { doses }\end{array}$ & $\begin{array}{l}\text { Buserelin dose } \\
\quad(\mathrm{mcg})\end{array}$ & $\begin{array}{c}\text { Response to } \\
\text { induction }\end{array}$ \\
\hline \multirow[t]{5}{*}{1} & 4.0 & 5 & 180 & 2 & 2.1 & Negative \\
\hline & 4.5 & 4 & 170 & 2 & 2.1 & Positive \\
\hline & 5.0 & 4 & 200 & 2 & 2.1 & Positive \\
\hline & 4.0 & 3 & 180 & 1 & 2.1 & Positive \\
\hline & 6.0 & 5 & 175 & 1 & 2.1 & Positive \\
\hline Mean & 4.7 & 4.2 & 181 & & & \\
\hline $\mathrm{SD}$ & \pm 0.83 & \pm 0.83 & \pm 11.40 & & & \\
\hline \multirow[t]{5}{*}{2} & 38.0 & 3 & 240 & 2 & 4.2 & Negative \\
\hline & 35.0 & 4 & 210 & 2 & 4.2 & Positive \\
\hline & 13.0 & 3 & 240 & 2 & 4.2 & Negative \\
\hline & 15.0 & 3 & 200 & 1 & 4.2 & Positive \\
\hline & 18.0 & 4 & 205 & 2 & 4.2 & Positive \\
\hline Mean & 23.8 & 3.4 & 219 & & & \\
\hline $\mathrm{SD}$ & \pm 11.77 & \pm 0.54 & \pm 19.49 & & & \\
\hline
\end{tabular}

Ten days after the first administration, seven female dogs had not shown clinical and cytological characteristics of proestrus and estrus (Table 1). These dogs received a second dose of buserelin, at a concentration equal to that of the first administration. Of these, three were from Group 1 (receiving a dose of $2,1 \mathrm{mcg} /$ animal), and four were female dogs from Group 2 (receiving a dose of $4,2 \mathrm{mcg} / \mathrm{animal}$ ). Of the seven female dogs that received a second dose of the drug, four showed clinical and cytological signs of proestrus and then of estrus, on average of $9 \pm 2.73$ days after the second administration. Two of these dogs were from Group 1, and two 
were from Group 2. Three female dogs did not respond even after the second administration of buserelin, one from Group 1 and two from Group 2.

The seven female dogs that showed estrus after induction were bred by natural mating, without restrictions on the number of copulations, and all became pregnant. Therefore, $100 \%$ pregnancy rate was observed in these animals, when the estrus was induced with buserelin.

Gunay (2004) used females in different anestrous phases: starting (108 to 124 days), and ending (160 to 187 days). They administered cabergoline (prolactin inhibitor) daily, at a dose of $6 \mathrm{mcg} / \mathrm{kg}$, orally, for 14 days. It was found that the average onset of response to the treatment was $11.3 \pm 2.8$ days. These results match those observed in this experiment, despite the use of a drug other than buserelin.

With regard to the vaginal cytology, it was observed that the animals showed similar cellular characteristics, with a progression from anestrus to proestrus and later to estrus. This progression was demonstrated by a gradual increase in the percentage of superficial cells. In the three female dogs responsive after a single administration of buserelin $(30 \%)$, there was a predominance of parabasal cells. However, superficial cells were also observed, evidencing the fast development of proestrus. In the animals induced after the second administration of buserelin, it was observed that, after nine days, they still showed parabasal cells in the vaginal smear. This represents a slower development of proestrus. Fourteen days after the second dose of buserelin, with the exception of the non-induced dogs, vaginal cytology revealed $90 \%$ surface cells. The superficial cells varied only in the percentages of anucleate cells and cells with pyknotic nuclei, which was typical of the estrous phase.

Johnston et al. (2001) and Ribeiro et al. (2007) stated that the maximum percentage of cell cornification, which reflects maximum estrogen stimulation, is between 80 and $90 \%$, in most animals. The type and intensity of the staining can contribute to an anucleate appearance of cells. In this experiment, when evaluating the characteristics of the vaginal cytology, influenced by exogenous hormonal induction, a reduced proestrus was observed in all animals. However, the progression intensities were different.

England \& Allen (1991); Ribeiro et al. (2007) induced estrus in female dogs by administering 20IU of eCG, once daily for five days, along with 500IU of hCG on the fifth day, and in the group of animals in spontaneous estrus. With vaginal cytology, they noted that the cell cornification peak occurred earlier in animals subjected to estrus induction, when compared to animals undergoing natural estrus, what did not happen in this work.

\section{CONCLUSIONS}

Intramuscular administration of buserelin acetate was effective in inducing estrus, when administered in two doses on average 10 days apart, allowing fertilization through natural mating.

\section{REFERENCES}

CONCANNON, P.W.; MCCANN, J.P.; TEMPLE, M. Biology and endocrinology of ovulation, pregnancy, and parturition in the dog. J. Reprod. Fertil. Suppl., v.39, p.3-25, 1989.

CONCANNON, P.W.; VERSTEGEN, J. Estrus induction in dogs: use of gonadotropins, therapies, and dopamine agonists. Pract. Ann Meeting Soc. Ther., v.7, p.240-245, 1997.

ENGLAND, G.C.W.; ALLEN, W.E. Repeatability of events during spontaneous and gonadotrophin-induced oestrus in bitch. $J$. Reprod.Fertil., v.93, p.443-448, 1991.

GUNAY, A. Cabergoline applications in early and late anoestrus periods on German shepherd dogs. Res. Med. Vet., v.155, p.557-560, 2004.

JHONSTON, S.D.; KUSTRITZ, M.V.R.; OLSON, P.N.S. Sexual differentiation and normal anatomy of the bitch. In: JHONSTON, S.D.; KUSTRITZ, M.V.R.; OLSON, P.N.S. Canine feline theriogenology. Philadelphia: W.B. Saunders Company, 2001. v.1, p.1-14.

KUTZLER, M.A. Induction and synchronization of in dogs. Theriogenology, v.64, p.766-775, 2005. 
LANNA, L.L.; MARQUES JUNIOR, A.P.; DOUGLAS, R.H. Effect of deslorelin on the induction of estrus in anestrous bitches. Arq. Bras. Med. Vet. Zootec., v.62, p.615-621, 2010.

OLIVEIRA, E.C.S.; MARQUES JÚNIOR, A.P. Endocronologia reprodutiva e controle da fertilidade da cadela. Rev. Bras. Reprod. Anim., v.30, p.11-18, 2006
RIBEIRO, A.P.C.; VICENTE, W.R.R.; SANTOS, I.W. et al. Gonadotrofinas na indução do estro em cadelas. Rev. Bras. Saúde Prod. Anim., v.8, p.324-334, 2007

RUIZ, J.R.; SERNA, C.J.T.; ECHEVERRI, C.A.G. Evaluation of prostaglandin $\mathrm{F}_{2 \alpha}$, estradiol benzoate and deslorelin acetate protocol for estrus induction in bitches. Arch. Med. Vet., v.47, p.395-399, 2015. 